\title{
Communication/Comunicação
}

\section{Improvement of a PCR test to diagnose infection by Mansonella ozzardi}

\author{
Adequação da técnica da PCR para diagnóstico de infecção de Mansonella ozzardi
}

\author{
Luana Janaína Souza Vera ${ }^{1}$, Sergio de Almeida Basano ${ }^{1,2}$, Juliana de Souza Almeida Aranha Camargo ${ }^{1}$, \\ Andonai Krauze de França ${ }^{3}$, Ricardo de Godoi Mattos Ferreira ${ }^{4}$, Almeida Andrade Casseb $^{3}$, Jansen Fernandes \\ Medeiros $^{5,6}$, Gilberto Fontes ${ }^{7}$ and Luís Marcelo Aranha Camargo ${ }^{1,8}$
}

\begin{abstract}
Introduction: Mansonelliasis is caused by Mansonella ozzardi. It is widespread in the Amazon region, with a high prevalence. The common exam of thick blood smears stained with Giemsa shows low efficacy levels and has been an obstacle to diagnosing individuals with low blood parasitemia. Methods: In order to increase diagnosis efficacy, the PCR technique was improved. Results and Conclusions: PCR demonstrated the best performance, with sensitivity and negative predictive values (NPV) of $100 \%$, followed by blood filtration through membrane filters, which showed a sensitivity of $88.9 \%$ and a NPV of $84.6 \%$, when compared to thick blood smears.
\end{abstract}

Keywords: Mansonella ozzardi. Diagnosis. PCR.

\section{RESUMO}

Introdução: A mansonelose é uma filariose causada pela Mansonella ozzardi, ocorrendo na Amazônia com prevalências de até 60\%. A técnica de diagnóstico habitual (hemoscopia através da gota espessa) tem baixa eficácia o para o diagnóstico de pacientes com baixa parasitemia. Métodos: Neste contexto foi aperfeiçoada a técnica da PCR para seu diagnóstico. Resultados e Conclusões: Quando comparada à gota espessa, a PCR apresenta sensibilidade de $100 \%$, e valor preditivo negativo (VPN) de $100 \%$ mostrando eficácia bastante superior à técnica da filtração em membrana que apresenta sensibilidade de $88,9 \%$ e VPN de $84,6 \%$, quando também comparada à gota espessa de sangue.

Palavras-chaves: Mansonella ozzardi. Diagnóstico. PCR.

The microfilariae of Mansonella ozzardi (Nematode, Onchocercidae) is the etiological agent of the mansonelliasis. The parasite has a geographic distribution limited to the Americas and it is found from Mexico through Argentina, except Chile, Uruguay, and Paraguay ${ }^{1}$. This filariasis was first reported in Brazil in the City of Manaus in the State of Amazonas ${ }^{2}$ and people infected by M. ozzardi were later identified along the Solimoes, Purus and Negro Rivers ${ }^{3}$. These findings reinforce many studies that have warned that M. ozzardi was widely distributed in the State of Amazonas ${ }^{4}$, Brazil; however studies concerning this filariasis remain scarce $\mathrm{e}^{5-7}$.

1. Coordenação de Medicina, Faculdade São Lucas, Porto Velho, RO. 2. Setor de Isolamento, Centro de Medicina Tropical de Rondônia, Porto Velho, RO. 3. Laboratório de Genética, Instituto de Pesquisa em Patologias Tropicais, Porto Velho, RO. 4. Laboratório de Estudos em Bioinformática e Bioestatística, Fundação Oswaldo Cruz Noroeste, Porto Velho, RO. 5. Coordenação de Pesquisas em Ciências da Saúde, Instituto Nacional de Pesquisas da Amazônia, Manaus, AM. 6. Escola Superior de Ciências da Saúde, Coordenação de Medicina, Universidade Estadual do Amazonas, Manaus, AM. 7. Centro de Ciências da Saúde, Universidade Federal de São João Del Rei, Divinópolis, MG. 8. Departamento de Parasitologia, Instituto de Ciências Biomédicas 5, Monte Negro, RO.

Address to: Dr. Luís Marcelo Aranha Camargo. Rua Francisco Prestes s/n, 76888-000 Monte Negro, RO, Brasil.

e-mail: spider@icb5usp.org

Received in 07/08/2010

Accepted in 16/11/2010
Mansonella ozzardi is transmitted by insects of the families Ceratopogonidae and Simuliidae (Diptera). Up to now, only the Simuliidaes have been identified as vectors in Brazil ${ }^{8,9}$. Infection symptomatology has been widely discussed and according to Batista et $\mathrm{al}^{10}$, people suffering from mansonelliasis present moderate fever, leg coldness, joint aches, dizziness and headaches. Recently, new symptomatology has been attributed to this filariasis, which is characterized by ocular lesions and white rings on the cornea that may eventually cause blindness ${ }^{11}$.

Typically, microscopic examination of a thick blood smear (TBS) stained with Giemsa, has been the main method used in epidemiological assays. Despite the low efficacy of TBS, particularly for patients with low microfilaremia, it is more economically feasible, promptly and easily obtained, and also permits identification of the parasite species even in locations where intermingled infections by other filariidaes occur ${ }^{12}$. More laborious and effective methods are feasible, such as Knott's concentration method (blood lysis by $2 \%$ formalin $)^{12,13}$, and by filtering the blood through a polycarbonate membrane filter $(\mathrm{PMF})^{12}$. The PMF is considered the gold-standard. Morales-Rojas et al first suggested polymerase chain reaction (PCR) as an effective method to detect M. ozzardi $i^{14}$.

This study aimed to standardize the PCR for diagnosing M. ozzardi and compare its effectiveness in relation to the PMF, which is considered the gold-standard for diagnosing the disease compared to the traditional TBS method.

Forty-seven patients infected by M. ozzardi were randomly selected from 232 individuals diagnosed by PMF (Poretics Corporation, Livermore, USA). These individuals lived alongside the rivers in the municipality of Labrea, State of Amazonas, Brazil $\left(07^{\circ} 15^{\prime} \mathrm{S} 64^{\circ} 51^{\prime} \mathrm{W}\right)$, an area with high prevalence of mansonelliasis. The TBS method was used according to the following procedure: blood was collected from the digital pulp (equivalent to $0.06 \mathrm{~mL}$ ) using disposable lancets and then prepared on microscope slides and left to dry at room temperature. Next, the slides were washed with distilled water, fixed with methanol, stained with Giemsa and dried off. The slides were then subjected to microscopic examination using optical objectives of $10 x$ and $40 x$ by two professionals in a blind controlled trial. PMF was conducted by filtering $1 \mathrm{~mL}$ of venous blood previously diluted with saline $0.9 \%$ through a polycarbonate membrane filter of 3-micrometer pore diameter size (Poretics Corporation - Livermore-USA) ${ }^{12}$.

The PCR method was based on the detection of the GenBank AF228564 DNA fragment from M. ozzardi which comprises the partial sequence of the $18 \mathrm{~S}$ ribosomal RNA gene, the internal transcribed spacer 1 , the complete sequence of the $5.8 \mathrm{~S}$ ribosomal 
RNA gene and internal transcribed spacer 2 (ITS2) and the partial sequence of the $28 \mathrm{~S}$ ribosomal RNA gene ${ }^{13}$. The forward primer used was 5'GAAAGAAGAAGGATTTTACT3' on the ITS2 and the reverse primer used was 5'CTTТССТCCGCTTAATTATA3' on the $28 \mathrm{~S}$ ribosomal DNA. These genes are commonly used for species identification on molecular bases since they comprise highly conserved sequences next to highly variable ones. The primers were verified using the NCBI primer design on-line tool based on the Primer $3{ }^{15}$ software and showed no unintended DNA products.

Genomic DNA was extracted from the samples according to the instructions of the Quiamp DNA Blood Kit (Qiagen ${ }^{\circledR}$ ). Blood samples of newborns from the city of Porto Velho were taken as negative control. The eluted DNA were maintained in microtubules and stored at $-20^{\circ} \mathrm{C}$. The following procedure was used to amplify the DNA sequence: the samples were maintained A) at a temperature of $94^{\circ} \mathrm{C}$ for $4 \mathrm{~min}(1 \mathrm{cycle}) ; \mathrm{B}$ ) at $94^{\circ} \mathrm{C}$ for $45 \mathrm{sec}$; at $55^{\circ} \mathrm{C}$ for $30 \mathrm{sec} ; 72^{\circ} \mathrm{C}$ for $45 \mathrm{sec}(35 \mathrm{cycles})$; C) $72^{\circ} \mathrm{C}$ for $5 \mathrm{~min}$ ( 1 cycle), and D) $4^{\circ} \mathrm{C}$ for $1 \mathrm{~min}$ (final time). The amplification product up to $312 \mathrm{bp}$ was viewed on $10 \%$ polyacrylamide gel with bromide staining (Figure 1).

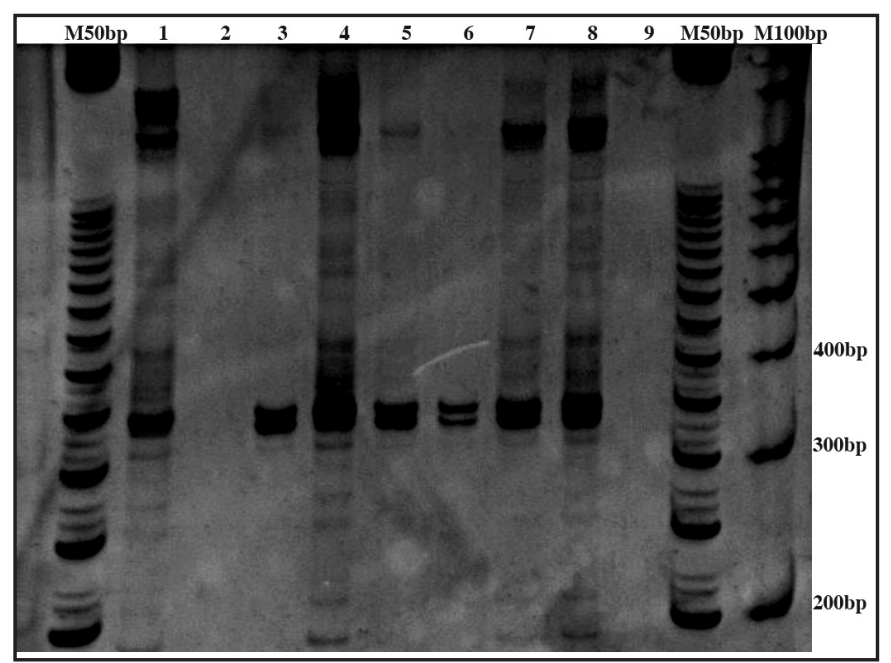

FIGURE 1 - Electrophoresis in 10\% polyacrylamide gel showing the PCR results for DNA extracted from blood.

M50pb stands for the 50 base pairs size marker, M100bp for the 100 base pairs size marker and the numbered lanes are: 1 : sample 709, positive control; 2: newborn 90, negative control; 3-8: samples 704, 708, 711, 712, 714 and 715; 9: sterile water negative control.

Both the PMF and PCR methods were compared to the common method for M. ozzardi diagnosis (TBS). In order to compare the effectiveness of the methods, the following parameters were considered: sensitivity, specificity, negative predictive value (NPV), and Cohen's kappa coefficient (Tables 1 and 2). The OpenEpi ${ }^{\circledast}$ software was used for statistical analysis, with a confidence interval (CI) of 95\%. The project was submitted to the Research Ethics Committee of the São Lucas College, Porto Velho and was approved under the registry number 344/09.

Of the 29 individuals who presented negative by TBS, $62.1 \%$ were identified as positive by PMF, while among the 18 who were positive by the TBS method, $88.9 \%$ showed the same results by PMF. On the other hand, TBS diagnosed 2 cases that were not diagnosed by PMF (false-negatives), despite its greater sensitivity. Regarding the PCR technique, $89.6 \%$ of those who presented negative by TBS were positive by PCR, while $100 \%$ of the positive cases showed the same results by PCR. Thus, the PCR technique showed the greatest
TABLE 1 - Effectiveness parameters of the polycarbonate membrane filtering method and the thick blood smear exam.

\begin{tabular}{lccc}
\hline Laboratory method & Positive TBS & Negative TBS & Total \\
\hline Positive PMF & 16 & 18 & 34 \\
\hline Negative PMF & 2 & 11 & 13 \\
\hline Total & $\mathbf{1 8}$ & $\mathbf{2 9}$ & $\mathbf{4 7}$ \\
\hline Sensitivity & $88.9 \%$ & $(67.2-96.9)^{*}$ & \\
\hline Specificity & $37.9 \%$ & $(22.69-56.0)^{*}$ & \\
\hline Negative predictive value & $84.6 \%$ & $(57.76-95.67)^{*}$ & \\
\hline Kappa coefficient & 0.2 & $(0.004-0.40)^{*}$ & \\
\hline $\begin{array}{l}\text { TBS: thick blood smear exam, PMF: polycarbonate membrane filtering method. } \\
\text { *confidence interval. }\end{array}$
\end{tabular}

TABLE 2 - Effectiveness parameters of the polymerase chain reaction and the thick blood smear exam.

\begin{tabular}{lccc}
\hline Laboratory method & Positive TBS & Negative TBS & Total \\
\hline Positive PCR & 18 & 26 & 44 \\
\hline Negative PCR & 0 & 3 & 3 \\
\hline Total & $\mathbf{1 8}$ & $\mathbf{2 9}$ & $\mathbf{4 7}$ \\
\hline Sensitivity & $100.0 \%$ & $(82.41-100.0)^{*}$ & \\
\hline Specificity & $10.3 \%$ & $(3.6-26.4)^{*}$ & \\
\hline Negative predictive value & $100.0 \%$ & $(43.8-100.0)^{*}$ & \\
\hline Kappa coefficient & 0.08 & $(-0.03-0.19)^{*}$ &
\end{tabular}

TBS: thick blood smear exam, PCR: polymerase chain reaction, ${ }^{*}$ confidence interval.

sensitivity and NPV, followed by PMF, when compared to TBS. However, both these methods showed low specificity and low kappa coefficient compared to TBS.

Despite the encouraging results, the cost of PCR is approximately US $\$ 8.60$ per test, while PMF has a significantly lower cost, US $\$ 0.80$ (author's personal information). The difficulties of performing PCR under field conditions must also be taken into account, since this is an important limiting factor in its application. Traditionally, studies concerning the prevalence of the M. ozzardi indicate its low prevalence rate in young individuals ${ }^{6-8}$, which is probably due to their low microfilaria concentration. The advent of PCR for mansonelliasis diagnosis, which shows $100 \%$ sensitivity, may help correct this bias by providing new epidemiological information on parasitic infections and by promoting the determination of higher prevalence rates.

\section{ACKNOWLEDGMENTS}

To Prof. Marisis Camargo for the English review of the manuscript.

\section{CONFLICT OF INTEREST}

The authors declare that there is no conflict of interest.

\section{FINANCIAL SUPPORT}

Fapesp 2008/10817-6.

\section{REFERENCES}

1. Tavares AM, Fraia Neto H. Mansonelose. In: Queiroz-Leao RN, editor. Doenças infecciosas e parasitarias. Manaus: Enfoque Amazônico; 1997. p. 733-737.

2. Deane MP. Sobre a incidência de filárias humanas em Manaus, Estado do Amazonas. Rev Fundação SESP 1949; 2:849-858. 
3. Lacerda NB, Rachou RG. Filarioses humanas nas sedes municipais do Estado do Amazonas e territórios do Acre, Guaporé e Rio Branco. Rev Bras Malariol Doencas Trop 1956; 8:437-442.

4. Moraes MAP, Almeida MMR, Lovelace KJ, Chaves GM. Mansonella ozzardi entre índios Ticunas do estado do Amazonas, Brasil. Bol Oficina Sanit Panam 1978; 85:16-25.

5. Medeiros JF, Py-Daniel V, Barbosa VE, Ogawa GM. Current profile of Mansonella ozzardi (Nematoda: Onchocercidae ) in communities along the Ituxi river, Labrea municipality, Amazonas Brazil. Mem Inst Oswaldo Cruz 2008; 103:409-411.

6. Medeiros JF, Py-Daniel V, Barbosa UC, Izzo TJ. Mansonella ozzardi in Brazil: prevalence of infection in riverine communities in the Purus region, in the state of Amazonas. Mem Inst Oswaldo Cruz 2009; 104:74-80.

7. Martins M, Pessoa FAC, Medeiros MB, Andrade EV, Medeiros JF. Mansonella ozzardi in Amazonas, Brazil: prevalence and distribution in the municipality of Coari, in the middle Solimões River. Mem Inst Oswaldo Cruz 2010; 105:246-253.

8. Cerqueira NL. Sobre a transmissão da Mansonella ozzardi. J Bras Med 1959; 1:885-914.

9. Shelley AJ, Luna Dias APA, Moraes MAP. Simulium species of amazonicum group as vectors of Mansonella ozzardi in the Brazilian Amazon. Trans R Soc Trop Med Hyg 1980; 74:784-788.

10. Batista D, Oliveira WR, Rabello VD. Estudo da patogenicidade da Mansonella ozzardi e da sintomatologia da Mansonelose. Rev Inst Med Trop Sao Paulo 1960; 2:281-289.

11. Branco BC, Chamon W, Belfort Neto R, Belfort-Costa Jr AJA. Achados oculares entre habitantes do município de Pauini e possível associação entre lesões corneanas e mansonelose na Amazônia. Arq Bras Oftalmol 1998; 61:674-682.

12. Fontes G, Rocha EMM. Wuchereria bancrofti - Filariose Linfática. In: Neves DP, Melo AL, Linardi PM, Vitor RWA, editors. Parasitologia Humana. $11^{\text {th }}$ ed. Rio de Janeiro: Atheneu; 2005. p.299-307.

13. Knott J. A Method for making microfilarial surveys on day blood. Trans R Soc Trop Med Hyg 1939; 33:191-196.

14. Morales-Hojas R, Port RJ, Shelley AJ, Maia-Herzog ER, Coscaron S, Sheke RA. Characterization of nuclear ribosomal DNA seqüences from Onchocerca volvulus and Mansonella ozzardi (Neumatoda: Filariodea) and development of a PCR based method for their detection in skin biopsies. Int J Parasitol 2001; 31:169-177.

15. Rozen S, Skaletsky HJ. Primer3 on the WWW for general users and for biologist programmers. In: Krawetz S, Misener S, editors. Bioinformatics Methods and Protocols: Methods in Molecular Biology. Totowa (NJ): Humana Press; 2000. p. 365-386 